\title{
Physicochemical properties of aromatic rice prepared using different milling recoveries and roasting procedures
}

\author{
Dae-Hoon Lee ${ }^{1}$, Hye-Mi Park ${ }^{1}$, Jun-Hyeon $\mathrm{Cho}^{2}$, Woo-Duck Seo ${ }^{3}$, Joo-Heon Hong ${ }^{1}$, \\ Kwang-Sup Youn ${ }^{1,4 *}$ \\ ${ }^{1}$ Department of Food Science and Technology, Daegu Catholic University, Gyeongsan 38430, Korea \\ ${ }^{2}$ Department of Southern Area Crop Science, NICS, RDA, Miryang 50424, Korea \\ ${ }^{3}$ Crop Foundation Division, NICS, Wanju 55365, Korea \\ ${ }^{4}$ Institute of Food Science and Technology, Daegu Catholic University, Gyeongsan 38430, Korea
}

\section{도정률 및 로스팅 조건에 따른 향미벼의 이화학적 품질특성}

\author{
이대훈 ${ }^{1} \cdot$ 박혜미 $^{1} \cdot$ 조준현 $^{2} \cdot$ 서우덕 $^{3} \cdot$ 홍주헌 $^{1} \cdot$ 윤광섭 $^{1,4 *}$ \\ ${ }^{1}$ 대구가톨릭대학교 식품공학전공, ${ }^{2}$ 농촌진흥청 국립식량과학원 남부작물부, \\ ${ }^{3}$ 농촌진흥청 국립식량과학원 작물기초기반과, ${ }^{4}$ 대구가톨릭대학교 식품과학연구소
}

\begin{abstract}
In this study, the physicochemical properties of aromatic rice prepared using different milling recoveries and roasting procedures were investigated. As a result, we found that the $L$ value of different milling recoveries of aromatic rice (BA-1, BA-2, BA-4, and BA-6) increased as the aromatic rice (BA-0) decreased, while the a and $\mathrm{b}$ values decreased as the different milling recoveries increased. The major contributors to the different milling recoveries of aromatic rice were total polyphenol $(28.11-33.84 \mathrm{mg} / 100 \mathrm{~g}$ ), amylose $(24.97-31.06 \mathrm{mg} / 100 \mathrm{~g})$, total starch (68.27-73.04\%) content. In addition, three different roasting methods were applied; the aromatic rice was roasted at $250^{\circ} \mathrm{C}$ for $0 \mathrm{~min}(\mathrm{BAR}-0 \mathrm{M}), 15 \mathrm{~min}(\mathrm{BAR}-15 \mathrm{M})$, or $30 \mathrm{~min}$ (BAR-30M). As a result, the color in terms of the $L$ value decreased, whereas the $a$ and $b$ values increased. Also, the total phenolic and flavonoid contents in BAR-30M $(41.65 \mathrm{mg} / 100 \mathrm{~g}$ and $22.30 \mathrm{mg} / 100 \mathrm{~g}$, respectively) were higher than those in BAR-0M $(33.00 \mathrm{mg} / 100$ $\mathrm{g}$ and $20.78 \mathrm{mg} / 100 \mathrm{~g}$, respectively). Similarly, the amylose and total starch contents in BAR-30M (26.10 g/100 $\mathrm{g}$ and $81.81 \%$, respectively) were higher than those in BAR-0M $(22.10 \mathrm{~g} / 100 \mathrm{~g}$ and $74.26 \%$, respectively). Furthermore, the DPPH, superoxide radical scavenging activity, and ferric reducing antioxidant potential of BAR-0M at 5,000 $\mu \mathrm{g} / \mathrm{mL}$ were found to be $67.78 \%, 52.90 \%$, and $0.79 \mathrm{mM}$, respectively. Based on these results, we can conclude that in order to provide the best physicochemical characteristics of aromatic rice, it should be manufactured in the following conditions: $20 \%$ milling recovery of the aromatic rice and roasting at $250^{\circ} \mathrm{C}$ for $30 \mathrm{~min}$.
\end{abstract}

Key words : aromatic rice, milling recovery, roasting, physicochemical properties, antioxidant activities

\section{서 론}

식생활의 고급화 및 다양화와 쌀 시장 개방으로 인해

*Corresponding author. E-mail : ksyoun@cu.ac.kr

Phone : 82-53-850-3209, Fax : 82-53-850-3209

Received 6 April 2018; Revised 23 April 2018; Accepted 23 April 2018.

Copyright (c) The Korean Society of Food Preservation. All rights reserved.
매년 쌀 소비량이 감소하고 있어 농촌의 사회적 및 경제적 문제점이 발생하고 있다. 이를 해결하기 위해서는 쌀을 에 너지 공급원의 기능뿐만 아니라 생리활성이 풍부하고 맛 및 향이 우수한 품종 개발 및 가공기술이 개발되어야 한다 (1). 그 중 향미는 인도, 남미, 유럽 및 북동아시아 등에서 재배하고 있으며 자스민 및 옥수수와 같은 다양한 향을 가지고 일반미와 비교하면 고부가가치 쌀로 알려져 있다 (2). 그러나, 향미의 다양한 향 및 색을 가지는 품종 개발 및 유전적 연구는 이루어지고 있으나 가공 기술에 관한 
연구는 부족한 실정이다 $(3,4)$.

쌀의 껍질 부분을 제거한 현미는 도정률이 높은 백미에 비교하여 vitamin $\mathrm{B}$, 지방 및 단백질이 풍부하고 식이섬유 함량도 우수하기 때문에 현미를 백미로 도정할 때 도정률이 높아질수록 양적 감소와 호분층에 다량 함유된 각종 영양분 의 감소가 동시에 발생하게 된다(5). 또한, 우리나라의 경우 쌀은 주식인 밥으로 주로 이용되며 가공품으로서 떡 및 한과 등으로 이용되고 있어 영양물질의 손실 최소화와 현대 인의 미각에 맞는 적절한 도정 가공을 통해 기호성을 향상 할 수 있어야 한다(6).

향미의 생리활성을 향상시키기 위한 로스팅 처리는 식품 의 화학적 성분 조정, 물리적 성질, 색, 향기 및 조직감 등과 같은 다양한 품질에 영향을 미치는 것으로 보고되고 있다 $(7,8)$. 이러한 열처리 가공 기술은 식품의 저장 수명을 연장 하고 생리활성을 향상시키기 위한 목적으로 이용되어 왔는 다. 또한, 열처리가 일어나는 동안 식물체 내의 이화학적 변화에 의하여 페놀성 화합물이 증가된다는 연구결과가 보고되어 있으며, 증가된 총 폴리페놀 함량은 항산화 활성 과 양의 상관 관계가 있음이 보고된 바 있다(9). 따라서, 향미의 품종에 따라 폴리페놀 및 전분이 결합되어 있는 방식이 다르므로 열처리 조건에 따라 생리활성 성분 및 효과가 달라지므로 효율적인 열처리 방법의 연구가 필요하 다(10).

따라서 본 연구에서는 향미의 식품 가공용 소재로의 활 용을 위해 도정도별 시료를 제조한 다음 이화학적 특성을 확인 하였으며, 생리활성 향상을 위해 로스팅 조건을 다르 게 하여 이화학적 품질특성 및 항산화 활성에 대하여 조사 하였다.

\section{재료 및 방법}

\section{실험재료}

본 실험에 사용한 향미벼(북경미)는 국립식량과학원 남 부작물부에서 2016년도 수확한 시료를 제공받아 본 실험에 사용하였다. 제공 받은 향미벼는 이물질을 제거한 다음 $4{ }^{\circ} \mathrm{C}$ 에 냉장 보관하면서 도정 및 로스팅 실험에 사용하였다.

\section{시료 제조}

향미벼 $500 \mathrm{~g}$ 을 도정기(RSKM-5B, Tohoku Satake CO., Iwate-ken, Japan)로 도정하여 시료를 제조 하였으며, 도정 률별 시료는 수율을 기준으로 도정 무처리(BA-0), 도정률 별 10\%(BA-1), 20\%(BA-2), 40\%(BA-4) 및 60\%(BA-6)를 각각 제조 하였다. 로스팅 처리는 도정된 향미 $500 \mathrm{~g}$ 을 교반 기가 장착된 자동 전기 볶음기(THDRE-01, Taehwan automation Ind, Bucheon, Korea)로 $250^{\circ}$ 에서 로스팅 무처리(BAR-0M), 로스팅 15 분(BAR-15M) 및 30 분(BAR-30M)간 처리 하여
제조하였다. 색도, 아밀로오스 및 전분 함량 분석에 사용된 시료는 위의 방법으로 제조된 시료를 사용하였다. 그외의 분석에 사용된 시료는 $70 \%$ 에탄올에 시료 $30 \mathrm{~g}$ 을 첨가하고 $95^{\circ} \mathrm{C}$ 에서 5 시간 동안 환류냉각추출기(CA-1112, Eyela Co., Tokyo, Japan)로 추출 후 감압농축기(Model N-1N, Eyela Co., Tokyo, Japan)로 농축하였으며, 동결건조(FreeZone 2.5 , Labconco Co, Kansas city, MO, USA)하여 $-70^{\circ} \mathrm{C}$ 이하의 암소에 보관하면서 분석용 시료로 사용하였다.

\section{색도 측정}

향미의 색도 측정은 표준색도가 $\mathrm{Y}=94.5, \mathrm{a}=0.18, \mathrm{~b}=0.32$ 로 보정된 색차계(Chromameter CR400, Minolta Co, Osaka, Japan)를 사용하여, 밝기를 나타내는 L(lightness), 적색도를 나타내는 a(redness), 황색도를 나타내는 b(yellowness) 값을 측정하였으며, 색차 $\Delta \mathrm{E}$ 는 무처리 구간을 대조구로 하여 아래와 같이 계산하였다.

$$
\Delta \boldsymbol{E}=\sqrt{\triangle L^{2}+\Delta a^{2}+\Delta b^{2}}
$$

\section{갈색도 및 탁도}

갈색도 및 탁도는 시료 $2.5 \mathrm{~g}$ 에 증류수 $50 \mathrm{~mL}$ 를 가한 다음 실온에서 3 시간 동안 교반하였다. 교반(BS-31, Jeio Tech., Daejeon, Korea) 후 원심분리 $(3,000 \times g, 30$ 분 $)$ 하여 상층액을 얻은 다음 $420 \mathrm{~nm}$ 및 $590 \mathrm{~nm}$ 에서 흡광도 (Ultraspec 2100pro, Amersham Co., Uppsala, Sweden)를 측 정하였다.

\section{총 폴리페놀 및 총 플라보노이드 함량}

총 폴리페놀 함량은 Singleton법(11)에 따라 시료 $1 \mathrm{~mL}$ 에 1 N Folin Ciocalteu(Sigma-Aldrich Co., St. Louis, MO, USA) reagent $1 \mathrm{~mL}$ 를 혼합하여 반응 시킨 후 $20 \%$ sodium carbonate $1 \mathrm{~mL}$ 를 첨가하고 실온의 암소에서 30 분간 반응시 킨 다음 $725 \mathrm{~nm}$ 에서 흡광도(Ultraspec 2100pro, Biochrom Ltd.)를 측정하였다. 총 폴리페놀 함량은 tannic acid(SigmaAldrich Co.)를 정량하여 작성한 표준곡선으로부터 계산하 였다.

총 플라보노이드 함량은 $\operatorname{Davis(12)ㅇㅢ~ㅂㅏㅇㅂㅓㅂㅇㅡㄹ~ㅇㅡㅇㅇㅛㅇㅎㅏㅇㅕ~}$ 측정하였다. 시료 $1 \mathrm{~mL}$ 에 $5 \%$ sodium nitrite $150 \mu \mathrm{L}$ 를 혼합 하여 실온에서 6 분간 반응 시킨 후 $10 \%$ aluminium chloride $300 \mu \mathrm{L}$ 를 첨가하고 실온에서 5 분간 반응 시킨 다음 $1 \mathrm{~N}$ $\mathrm{NaOH} 1 \mathrm{~mL}$ 와 혼합한 후 $510 \mathrm{~nm}$ 에서 흡광도(Ultraspec 2100 pro, Biochrom Ltd.)를 측정하였다. 총 플라보노이드 함량은 rutin(Sigma-Aldrich Co.)을 정량하여 작성한 표준곡 선으로부터 계산하였다.

아밀로오스 함량 측정

아밀로오스 함량은 Williams 등(13)의 방법에 의해 측정 
하였다. 시료 $0.1 \mathrm{~g}$ 에 $95 \%$ ethanol $1 \mathrm{~mL}$ 과 $1 \mathrm{~N} \mathrm{NaOH} 9$ $\mathrm{mL}$ 를 첨가하여 분산시키고, 진탕 항온수조(BS-31, Jeio $\mathrm{Tech}$.)에 넣어 $100^{\circ} \mathrm{C}$ 에서 10 분 동안 반응시켰다. 반응용액 $5 \mathrm{~mL}$ 를 취하고 $1 \mathrm{~N}$ acetic acid $1 \mathrm{~mL}$ 와 iodine-potassium iodine 용액(w/v) $2 \mathrm{~mL}$ 를 첨가한 후 증류수를 이용하여 100 $\mathrm{mL}$ 가 되도록 정용하였으며, 30 분 동안 방치한 다음 620 $\mathrm{nm}$ 에서 흡광도(Ultraspec-2100pro, Amersham Co.)를 측정 하였다. 아밀로오즈함량은 amylose from potato(SigmaAldrich Co.)를 정량하여 작성한 표준곡선으로부터 계산하 였다.

\section{전분함량}

전분함량은 total starch kit(Megazyme international Ireland Ltd., Wicklow, Ireland)를 이용하여 제조사의 지침에 따라 측정하였다. 시료 $0.1 \mathrm{~g}$ 에 $80 \%$ 에탄올 $0.2 \mathrm{~mL}$ 를 가한 다음, 열에 안정한 a-amylase $3 \mathrm{~mL}$ 를 가하여 교반 후 끓는 물에서 6 분간 반응시켰다. 실온에서 $50^{\circ} \mathrm{C}$ 로 냉각 시킨 후 amyloglucosidase $0.1 \mathrm{~mL}$ 를 가하여 교반한 다음 $50^{\circ} \mathrm{C}$ water bath에서 30 분간 반응한 다음 시료를 $100 \mathrm{~mL}$ 로 정용한 후 $3,000 \mathrm{rpm}$ 에서 10 분간 원심분리 하였다. 원심분리된 상등 액 $0.1 \mathrm{~mL}$ 를 취하여 (D-Glucose Assay Kit)GOPOD 용액 $3 \mathrm{~mL}$ 를 가하고 $50^{\circ} \mathrm{C}$ 에서 20 분간 발색시킨 다음 $510 \mathrm{~mm}$ 에서 흡광도(Ultraspec- 2100pro, Amersham Co.)를 측정하였다. 전분 함량은 아래의 식으로 계산하였다.

\section{$\operatorname{Starch}(\%)=\Delta \mathrm{A} \times \mathrm{F} / \mathrm{W} \times \mathrm{FV} \times 0.9$}

$\Delta \mathrm{A}$ : absorbance

F : $100 \mu \mathrm{g}$ of D-glucose/absorbance for $100 \mu \mathrm{g}$ of D-glucose W : weight of sample

$\mathrm{FV}$ : final volume

\section{DPPH radical 소거활성}

$\mathrm{DPPH}$ radical 소거활성 측정은 1,1-diphenyl-2-picrylhydrazyl (DPPH, Sigma-Aldrich Co.)의 환원력을 이용하여 측정하였 다(14). $5 \mathrm{mg} / \mathrm{mL}$ 농도로 희석한 시료 $1 \mathrm{~mL}$ 에 $4 \times 10^{-4} \mathrm{M}$ $\mathrm{DPPH}$ 용액(99.9\% ethyl alcohol에 용해) $1 \mathrm{~mL}$ 를 가하여 총액의 부피가 $2 \mathrm{~mL}$ 가 되도록 하였다. 이 반응액을 약 10 초 간 혼합하고 실온에서 30 분 방치한 다음 $525 \mathrm{~nm}$ 에서 흡광 도(Ultraspec 2100pro, Amersham Co.)를 측정하였으며, $\mathrm{DPPH}$ radical 소거활성은 시료의 첨가 전과 후의 차이를 아래와 같이 백분율로 나타내었다.

DPPH Radical scavenging activity $(\%)=\left(1-\frac{\text { sample absorbance }}{\text { control absorbance }}\right) \times 100$

\section{Superoxide radical 소거활성}

Superoxide radical 소거 활성은 Nishikimi 등(15)의 방법
에 따라 다음과 같이 측정하였다. 시료 $500 \mu \mathrm{L}$ 에 $0.1 \mathrm{M}$ Tris- $\mathrm{HCl}$ 완충용액 $(\mathrm{pH} 8.5) 100 \mu \mathrm{L}, 100 \mu \mathrm{M}$ phenazine methosulfate(PMS, Sigma-Aldrich Co.) $200 \mu \mathrm{L}$ 를 혼합하여 반응 시킨 후 $500 \mu \mathrm{M}$ nitro blue tetrazolium(NBT, SigmaAldrich Co.) $200 \mu \mathrm{L}$ 및 $500 \mu \mathrm{M} \beta$-nicotinamise adenine dinucleotide(NADH, Sigma-Aldrich Co.) $400 \mu \mathrm{L}$ 를 첨가하여 실온에서 10 분간 반응시킨 다음 $560 \mathrm{~nm}$ 에서 흡광도 (Ultraspec 2100pro, Biochrom Ltd.)를 측정하였다. Superoxide radical 소거활성은 향미의 첨가 전과 후의 차이를 아래와 같이 백분율로 나타내었다.

Superoxide radical scavenging activity $(\%)=\left(1-\frac{\text { sample absorbance }}{\text { control absorbance }}\right) \times 100$

\section{FRAP}

Ferric reducing antioxidant potential(FRAP)법에 의한 환 원력은 Benzie와 Strain(16)의 방법에 따라 $300 \mathrm{mM}$ acetate buffer(pH 3.6), $40 \mathrm{mM} \mathrm{HCl}$ 에 용해한 $10 \mathrm{mM} \mathrm{TPTZ}$ (2,4,6-tripyridyl-s-triazine, Sigma-Aldrich Co.) 용액 및 20 $\mathrm{mM} \mathrm{FeCl}{ }_{3} \cdot 6 \mathrm{H}_{2} \mathrm{O}$ (Sigma-Aldrich Co.)를 각각 $10: 1: 1(\mathrm{v} / \mathrm{v} / \mathrm{v})$ 의 비율로 혼합하여 $37^{\circ} \mathrm{C}$ 의 수욕상에서 가온한 것을 FRAP 기질 용액으로 사용하였다. 96-well plate에 $5 \mathrm{mg} / \mathrm{mL}$ 농도로 희석한 시료액 $25 \mu \mathrm{L}$ 와 FRAP 기질액 $175 \mu \mathrm{L}$ 를 차례대로 혼합하여 $37^{\circ} \mathrm{C}$ 에서 4 분간 반응 시킨 후 microplate reader(UVM-340, ASYS Co.)를 사용하여 $590 \mathrm{~nm}$ 에서 흡광 도를 측정하였다.

\section{통계 처리}

실험결과는 3회 반복실험의 평균표준편차로 나타내었 고 $\operatorname{SPSS}(19.0, \mathrm{SPSS}$ Inc., Chicago, IL, USA)를 이용하여 분산분석(ANOVA)을 실시하였고 각 측정 평균값의 유의 성 $(\mathrm{p}<0.05)$ 은 Duncan's multiple range test로 검정하였다.

\section{결과 및 고찰}

\section{도정률별 향미의 이화학적 특성}

향미의 도정률별 이화학적 특성은 Table 1에 나타내었다. 색도는 무처리(BA-0) 구간에서 $\mathrm{L}$ 값, $\mathrm{a}$ 값 및 $\mathrm{b}$ 값이 각각 $81.76,1.20,13.10$ 을 나타내었으며, 도정(BA-1, BA-2, BA-4, $\mathrm{BA}-6)$ 구간에서는 도정률이 증가함에 따라 L 값(81.63$85.10)$ 은 증가하고 $\mathrm{a}$ 값(1.09-0.29) 및 b 값(12.90-10.42)은 감소하는 경향을 나타내었다. 특히 무처리를 기준으로 본 $\Delta \mathrm{E}$ 값은 $\mathrm{BA}-1$ 에서 0.26 으로 가장 낮고 BA-6에서 4.38로 가장 높게 나타나 도정률이 증가할수록 색의 변화가 증가하 였다. 도정률별 갈색도와 탁도는 도정률이 증가함에 따라 각각 0.32-0.40 및 0.15-0.26을 나타내어 무처리 구간 각각 
Table 1 . Hunter's color, browning degree and turbidity of aromatic rice prepared with different milling recovery

\begin{tabular}{|c|c|c|c|c|c|c|}
\hline \multirow{2}{*}{ Samples ${ }^{1)}$} & \multicolumn{3}{|c|}{ Hunter's color value } & \multirow{2}{*}{$\Delta \mathrm{E}$} & \multirow{2}{*}{$\begin{array}{l}\text { Browning degree } \\
\text { (A420) }\end{array}$} & \multirow{2}{*}{$\begin{array}{l}\text { Turbidity } \\
\text { (A590) }\end{array}$} \\
\hline & $\mathrm{L}$ & $\mathrm{a}$ & $\mathrm{b}$ & & & \\
\hline $\mathrm{BA}-0$ & $81.76 \pm 0.71^{(2)}$ & $1.20 \pm 0.11^{\mathrm{a}}$ & $13.10 \pm 0.35^{\mathrm{a}}$ & - & $0.55 \pm 0.03^{\mathrm{a}}$ & $0.42 \pm 0.03^{\mathrm{a}}$ \\
\hline BA-1 & $81.63 \pm 0.33^{c}$ & $1.09 \pm 0.05^{\mathrm{a}}$ & $12.90 \pm 0.12^{\mathrm{ab}}$ & $0.26 \pm 0.04^{\mathrm{a}}$ & $0.40 \pm 0.01^{\mathrm{b}}$ & $0.26 \pm 0.1^{b}$ \\
\hline BA-2 & $82.27 \pm 0.07^{\mathrm{c}}$ & $0.91 \pm 0.06^{b}$ & $12.57 \pm 0.01^{b}$ & $0.79 \pm 0.13^{b}$ & $0.39 \pm 0.01^{b}$ & $0.22 \pm 0.00^{c}$ \\
\hline BA-4 & $84.05 \pm 0.17^{b}$ & $0.53 \pm 0.09^{c}$ & $11.02 \pm 0.32^{c}$ & $3.17 \pm 0.34^{\mathfrak{c}}$ & $0.36 \pm 0.01^{\mathrm{c}}$ & $0.20 \pm 0.00^{\mathrm{c}}$ \\
\hline BA- 6 & $85.10 \pm 0.40^{\mathrm{a}}$ & $0.29 \pm 0.04^{\mathrm{d}}$ & $10.42 \pm 0.18^{\mathrm{d}}$ & $4.38 \pm 0.40^{\mathrm{d}}$ & $0.32 \pm 0.01^{\mathrm{d}}$ & $0.15 \pm 0.01^{\mathrm{d}}$ \\
\hline
\end{tabular}

${ }^{1)} \mathrm{BA}-0$, Aromatic rice; BA-1, $10 \%$ milling recovery of aromatic rice; BA-2, $20 \%$ milling recovery of aromatic rice; BA-4, $40 \%$ milling recovery of aromatic rice; BA-6, $60 \%$ milling recovery of aromatic rice.

${ }^{2)}$ The values are means $\pm \mathrm{SD}$ of three experimental data. Means with different superscripts in the same column are significantly different at $\mathrm{p}<0.05$.

0.55 및 0.42 에 비해 감소하는 경향을 나타내었다. 이는 Park 등의(17)의 제조조건에 따른 현미쌀가루의 품질특성 에서 도정에 의해 $\mathrm{L}$ 값은 높고 $\mathrm{a}$ 값 및 $\mathrm{b}$ 값은 낮게 나탄난다 고 보고하였으며, Kim 등(18)의 도정도에 따른 쌀의 칼라 모델링 연구에서 색도에서 0-20\% 범위에서 도정 후 L 값은 증가한다고 보고하여, 본 연구 결과와 유사한 경향을 나타 내다. 이는 향미의 도정 중 미강층이 감소하고 전분 배유층 이 나타남에 따라 색의 변화가 나타난 것으로 사료된다.

\section{도정률별 향미의 폴리페놀, 아밀로오스 및 전분 함량}

향미 도정률에 따른 총 폴리페놀, 아밀로오스 함량 및 전분 함량은 Table 2에 나타내었다. 총 폴리페놀 함량은 무처리 구간에서 $35.53 \mathrm{mg} / 100 \mathrm{~g}$ 을 나타내었으나, 도정률 이 증가함에 따라 28.11-33.84 mg/100 g으로 함량이 감소하 였다. 이는 $\operatorname{Kim}$ 등(19)의 품종 및 도정도별 총 폴리페놀 함량 연구에서 도정률이 증가함에 총 폴리페놀 함량은 유의 적으로 감소되었으며, Chang 등(20)도 도정률이 증가할수 록 총 페리페놀 함량이 감소한다고 보고하였다. 향미의 주요 페놀산은 대부분 pericarp와 aleurone layer을 포함한 왕겨층 및 미강층에 분포하고 있으며, 페놀산은 주로 식물 세포벽에 arabinoxylan에 ester 결합으로 존재하거나 lignan

Table 2. Total polyphenol, and amylose and total starch of aromatic rice prepared with different milling recovery

\begin{tabular}{cccc}
\hline Samples $)^{1)}$ & $\begin{array}{c}\text { Total polyphenol } \\
(\mathrm{mg} / 100 \mathrm{~g})\end{array}$ & $\begin{array}{c}\text { Amylose content } \\
(\mathrm{g} / 100 \mathrm{~g})\end{array}$ & $\begin{array}{c}\text { Total starch } \\
(\%)\end{array}$ \\
\hline BA-0 & $\left.35.53 \pm 0.42^{\mathrm{a} 2}\right)$ & $23.02 \pm 0.21^{\mathrm{d}}$ & $64.24 \pm 0.43^{\mathrm{e}}$ \\
BA-1 & $33.84 \pm 0.26^{\mathrm{b}}$ & $24.97 \pm 0.03^{\mathrm{c}}$ & $68.27 \pm 0.40^{\mathrm{d}}$ \\
BA-2 & $33.00 \pm 0.35^{\mathrm{b}}$ & $25.54 \pm 0.09^{\mathrm{b}}$ & $70.46 \pm 0.27^{\mathrm{c}}$ \\
BA-4 & $30.57 \pm 0.02^{\mathrm{c}}$ & $25.57 \pm 0.03^{\mathrm{b}}$ & $71.29 \pm 0.35^{\mathrm{b}}$ \\
BA-6 & $28.11 \pm 0.10^{\mathrm{d}}$ & $31.06 \pm 0.36^{\mathrm{a}}$ & $73.04 \pm 0.66^{\mathrm{a}}$ \\
\hline
\end{tabular}

${ }^{11} \mathrm{BA}-0$, Aromatic rice; BA-1, $10 \%$ milling recovery of aromatic rice; BA-2, $20 \%$ milling recovery of aromatic rice; BA-4, $40 \%$ milling recovery of aromatic rice; BA-6, $60 \%$ milling recovery of aromatic rice.

${ }^{2}$ The values are means $\pm \mathrm{SD}$ of three experimental data. Means with different superscripts in the same column are significantly different at $p<0.05$.
에 ester 및 ether 결합 상태로 존재하므로 이들 성분의 효율 적인 이용을 위한 도정률 선정은 중요한 것으로 판단된다 (21). 아밀로오스 함량 및 전분함량의 경우에는 무처리 구간 에서 $23.02 \mathrm{~g} / 100 \mathrm{~g}$ 및 $64.24 \%$ 를 나타내었으며, 도정률이 증가함에 따라 24.97-31.06 g/100 g 및 68.27-73.04\%으로 아밀로오스 및 전분 함량은 증가하는 경향을 나타내었다. 아밀로오스 함량은 쌀의 조리특성과 밥의 조직감이나 광택 등 기호도를 결정하는 가장 중요한 인자라고 보고되어 있으 며(22), Lee 등(23)은 무농약 재배 쌀의 특성 비교 연구에서 전분함량은 도정에 의해 감소하였으며, 이는 단백질, 지방 질, 회분 및 식이섬유 등이 감소하여 상대적으로 전분 함량 이 증가한 것으로 보고하였다. 따라서, 향미의 품질특성이 감소되지 않는 $20 \%$ 도정률 구간을 선정하여 향 후 실험을 진행하였다.

\section{로스팅 향미의 이화학적 특성}

향미의 로스팅 조건에 따른 이화학적 특성은 Table 3에 나타내었다. 로스팅 조건에 따른 색도는 향미 도정 후 로스 팅 무처리(BAR-0M) 구간에서 $\mathrm{L}$ 값, $\mathrm{a}$ 값 및 $\mathrm{b}$ 값이 각각 $83.53,0.66,11.61$ 을 나타내었으며, 도정 후 로스팅 구간 (BAR-15M 및 BAR-30M)에서는 로스팅 시간이 증가함에 따라 $\mathrm{L}$ 값(80.44-82.21)은 감소하고 $\mathrm{a}$ 값(0.79-1.48) 및 $\mathrm{b}$ 값(12.62-16.11)은 증가하는 경향을 나타내었다. 특히 무처 리를 기준으로 본 $\Delta \mathrm{E}$ 값은 $\mathrm{BAR}-30 \mathrm{M}$ 에서 5.53으로 가장 높게 나타나 로스팅 시간이 증가할수록 색의 변화가 증가하 였다. 로스팅 조건별 갈색도와 탁도는 로스팅 시간이 증가 함에 따라 각각 1.94-1.95 및 1.42-1.50를 나타내어 무처리 구간 각각 1.88 및 1.30 에 비해 갈색도 및 탁도는 증가하는 경향을 나타내었다. Ko 등의(24)의 볶음시간에 따른 수수 의 이화학적 특성 연구에서 볶음 시간이 증가할수록 $\mathrm{L}$ 값은 감소하고 $\mathrm{a}$ 값 및 $\mathrm{b}$ 값은 증가한다고 보고하여 본 연구 결과와 유사하였으며, 이는 향미의 로스팅 과정에서 maillard 반응에 의해 melanoidin 생성량 증가로 갈색도가 증가하는 것으로 알려져있다. 또한, 로스팅에 의한 향미의 조직 변화로 불용성 전분의 용출이 증가하여 탁도가 증가하 는 것으로 보고되어 있다(25). 
Table 3. Hunter's color, browning degree and turbidity of aromatic rice prepared with roasting

\begin{tabular}{|c|c|c|c|c|c|c|}
\hline \multirow{2}{*}{ Samples ${ }^{1)}$} & \multicolumn{3}{|c|}{ Hunter's color value } & \multirow{2}{*}{$\Delta \mathrm{E}$} & \multirow{2}{*}{$\begin{array}{l}\text { Browning degree } \\
\text { (A420) }\end{array}$} & \multirow{2}{*}{$\begin{array}{l}\text { Turbidity } \\
\text { (A590) }\end{array}$} \\
\hline & $\mathrm{L}$ & $\mathrm{a}$ & $\mathrm{b}$ & & & \\
\hline BAR-OM & $83.53 \pm 0.43^{\mathrm{a} 2)}$ & $0.66 \pm 0.03^{b}$ & $11.61 \pm 0.20^{c}$ & - & $1.88 \pm 0.00^{c}$ & $1.30 \pm 0.00^{c}$ \\
\hline BAR-15M & $82.21 \pm 0.26^{b}$ & $0.79 \pm 0.05^{b}$ & $12.62 \pm 0.18^{b}$ & $1.25 \pm 0.28^{b}$ & $1.94 \pm 0.01^{\mathrm{b}}$ & $1.42 \pm 0.00^{b}$ \\
\hline BAR-30M & $80.44 \pm 0.31^{c}$ & $1.48 \pm 0.10^{\mathrm{a}}$ & $16.11 \pm 0.41^{\mathrm{a}}$ & $5.53 \pm 0.50^{\mathrm{a}}$ & $1.95 \pm 0.00^{\mathrm{a}}$ & $1.50 \pm 0.01^{\mathrm{a}}$ \\
\hline
\end{tabular}

${ }^{1)}$ BAR-0M, 20\% milling recovery of aromatic rice; BAR-15M, 20\% milling recovery aromatic rice prepared with roasting for 15 min; BAR-30M, $20 \%$ milling recovery aromatic rice prepared with roasting for $30 \mathrm{~min}$.

${ }^{2)}$ The values are means $\pm \mathrm{SD}$ of three experimental data. Means with different superscripts in the same column are significantly different at $\mathrm{p}<0.05$.

\section{로스팅 향미의 총 폴리페놀 및 플라보노이드 함량, 아밀 로오스 및 전분 함량}

향미 로스팅 조건에 따른 총 폴리페놀 및 플라보노이드 함량, 아밀로오스 및 전분 함량은 Table 4에 나타내었다. 총 폴리페놀 및 플라보노이드 함량은 무처리 구간에서 $33.00 \mathrm{mg} / 100 \mathrm{~g}$ 및 $20.78 \mathrm{mg} / 100 \mathrm{~g}$ 을 나타내었으나, 로스팅 시간이 증가함에 따라 37.41-41.65 mg/100 g 및 21.93-22.30 $\mathrm{mg} / 100 \mathrm{~g}$ 으로 함량이 증가하였다. Kwan 등(25)은 열처리 온도에 따른 현미 에탄올 추출물의 항산화 성분 및 활성 변화 연구에서 고온에서 현미를 볶음 $\left(180^{\circ} \mathrm{C}\right)$ 처리 하는 동안 아미노산, 당 및 펩타이드 성분들이 maillard 반응으로 총 폴리페놀 및 페놀 유사 화합물들을 생성하여 총 폴리페놀 및 플라보노이드 함량이 증가한다고 보고하였다.

향미 로스팅 조건에 따른 아밀로오스 및 전분 함량 변화 는 로스팅 처리를 통해 각각 $25.06-26.10 \mathrm{~g} / 100 \mathrm{~g}$ 및 $76.38-81.81 \%$ 를 나타내어 무처리 구간 $22.10 \mathrm{~g} / 100 \mathrm{~g}$ 및 $74.26 \%$ 비해 전반적으로 함량이 증가하였으며, 특히, 로스 팅 30 분 처리 구간에서 가장 높은 함량 증가를 나타내었다. 이는 Lee(26)의 잡곡류를 가열처리한 다음 아밀로오스 및 전분 함량이 증가하였으며, 이러한 전분 함량의 증가는 식 품의 색, 조직, 촉감, 식품 성분의 유리방지 및 풍미 개선에 도움이 되는 것으로 보고되어 있다(27).

Table 4. Total polyphenol, total flavonoid, amylose and total starch of aromatic rice prepared with roasting

\begin{tabular}{ccccc}
\hline Samples ${ }^{1)}$ & $\begin{array}{c}\text { Total polyphenol } \\
\text { content } \\
(\mathrm{mg} / 100 \mathrm{~g})\end{array}$ & $\begin{array}{c}\text { Total flavonoid } \\
(\mathrm{mg} / 100 \mathrm{~g})\end{array}$ & $\begin{array}{c}\text { Amylose content } \\
(\mathrm{g} / 100 \mathrm{~g})\end{array}$ & $\begin{array}{c}\text { Total starch } \\
(\%)\end{array}$ \\
\hline BAR-0M & $33.00 \pm 0.35^{\mathrm{c} 2)}$ & $20.78 \pm 0.36^{\mathrm{b}}$ & $22.10 \pm 0.25^{\mathrm{c}}$ & $74.26 \pm 0.90^{\mathrm{c}}$ \\
BAR-15M & $37.41 \pm 0.41^{\mathrm{b}}$ & $21.93 \pm 0.38^{\mathrm{a}}$ & $25.06 \pm 0.22^{\mathrm{b}}$ & $76.38 \pm 0.41^{\mathrm{b}}$ \\
BAR-30M & $41.65 \pm 0.27^{\mathrm{a}}$ & $22.30 \pm 0.27^{\mathrm{a}}$ & $26.10 \pm 0.29^{\mathrm{a}}$ & $81.81 \pm 0.48^{\mathrm{a}}$ \\
\hline
\end{tabular}

${ }^{1)}$ BAR-0M, 20\% milling recovery of aromatic rice; BAR-15M, 20\% milling recovery aromatic rice prepared with roasting for $15 \mathrm{~min}$; BAR-30M, $20 \%$ milling recovery aromatic rice prepared with roasting for $30 \mathrm{~min}$

${ }^{2}$ The values are means \pm SD of three experimental data. Means with different superscripts in the same column are significantly different at $\mathrm{p}<0.05$.

\section{로스팅 향미의 항산화 활성}

로스팅 조건에 따른 향미의 항산화 활성을 확인하기 위
해 DPPH 및 superoxide radical 소거활성 및 ferric reducing antioxidant potential(FRAP)를 1,000-5,000 $\mathrm{\mu g} / \mathrm{mL}$ 농도에서 측정한 결과는 Fig. 1 및 2 와 같다. 로스팅 처리 구간의 $\mathrm{DPPH}$ 및 superoxide radical 소거활성은 $5,000 \mathrm{\mu g} / \mathrm{mL}$ 농도에 서 각각 61.56-67.78\% 및 43.14-52.90\%를 나타내어 무처리

(A)

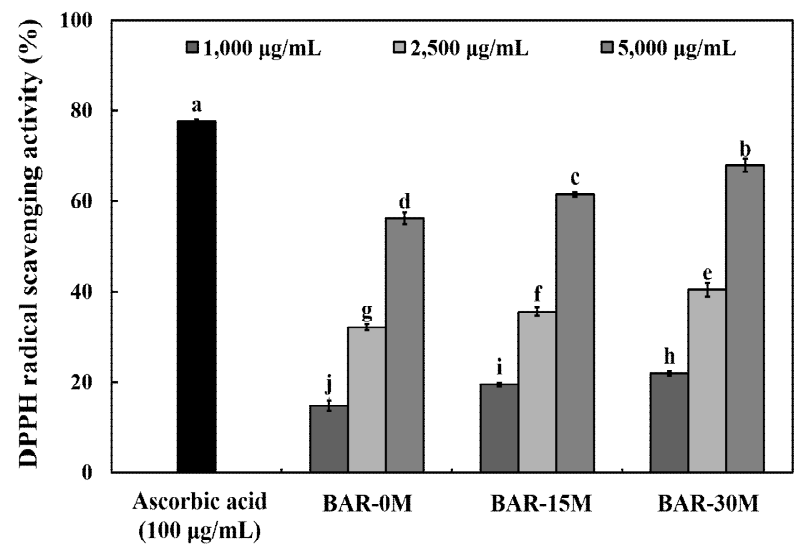

(B)

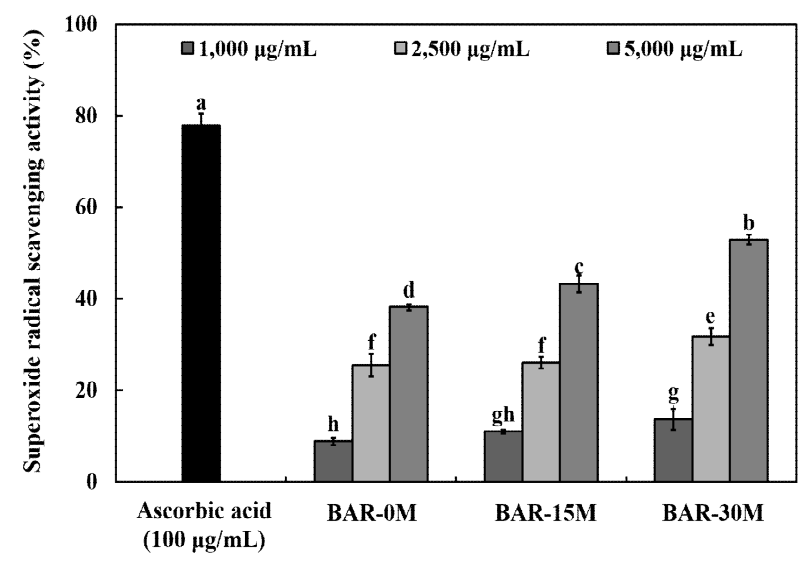

Fig. 1. DPPH radical scavenging (A) and superoxide radical scavenging (B) of aromatic rice prepared with different roasting. BAR-0M, $20 \%$ milling recovery of aromatic rice; BAR-15M, $20 \%$ milling recovery aromatic rice prepared with roasting for $15 \mathrm{~min}$; BAR-30M, $20 \%$ milling recovery aromatic rice prepared with roasting for $30 \mathrm{~min}$.

Means with different letters above the bars are significantly different $(\mathrm{p}<0.05)$. 
구간 $56.25 \%$ 및 $38.19 \%$ 에 비해 우수한 항산화 활성을 나타 내었다. 또한, FRAP 활성에서도 로스팅 처리 구간에서 0.72-0.79 $\mathrm{mM}$ 을 나타내어 무처리 구간 $0.65 \mu \mathrm{M}$ 에 비해 우수한 항산화 활성을 나타내었으며, 특히, 로스팅 30 분 처리 구간에서 가장 높은 항산화 활성을 나타내었다. 이는 향미에 함유되어 있는 페놀 성분 함량이 항산화 활성을 나타내는 중요한 척도로 알려져 있으며(28), Lee 등(29)의 볶음 및 침출 조건에 따른 발아 벼차의 항산화 활성 연구에 서 볶음 시간이 증가할수록 총 페놀 함량의 증가에 의해 높은 항산화 활성을 나타낸다고 보고하여 본 연구결과와 유사한 경향을 나타내었다. 또한, kiligaya 등(30)의 갈색화 반응 물질인 melanoidin에 의한 항산화력과 항산화 활성은 갈색도와 비례관계에 있다고 보고되어 있다. 따라서, 향미 는 도정 후 로스팅에 의한 갈색화, 폴리페놀 및 플라보노이 드 함량 증가에 의해 항산화 활성이 증진된 것으로 사료된 다.

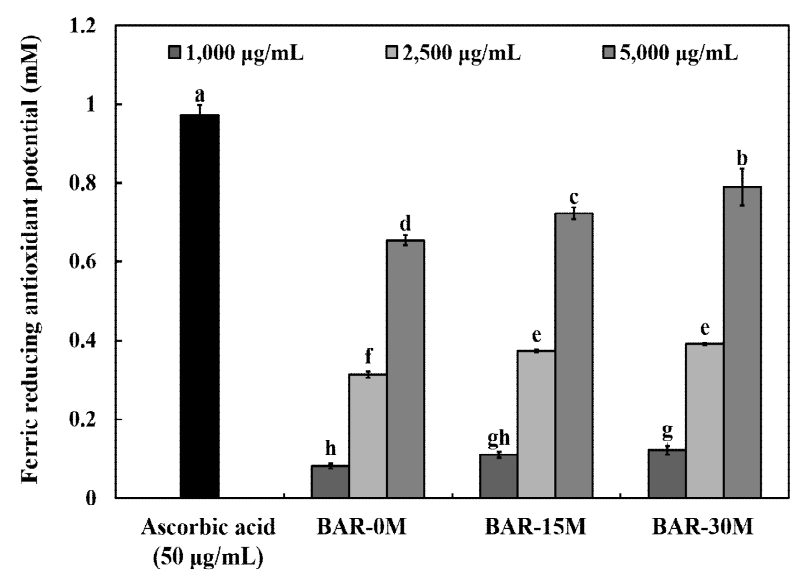

Fig. 2. Ferric reducing antioxidant potential of aromatic rice prepared with different roasting.

BAR-0M, 20\% milling recovery of aromatic rice; BAR-15M, 20\% milling recovery aromatic rice prepared with roasting for $15 \mathrm{~min}$; BAR-30M, $20 \%$ milling recovery aromatic rice prepared with roasting for $30 \mathrm{~min}$.

Means with different letters above the bars are significantly different $(\mathrm{p}<0.05)$.

\section{요 약}

향미의 도정률에 따른 색도는 도정률이 증가할수록 $\mathrm{L}$ 값은 증가하고 $\mathrm{a}$ 값 및 $\mathrm{b}$ 값은 감소하였으며, 갈색도 및 탁도는 감소하는 경향을 나타내었다. 총 폴리페놀, amylose 및 전분 함량은 도정률이 증가할수록 각각 28.11-33.84 $\mathrm{mg} / 100 \mathrm{~g}, 24.97-31.06 \mathrm{mg} / 100 \mathrm{~g}$ 및 68.27-73.04\%로 폴리페 놀은 감소하고 아밀로오스 및 전분 함량은 증가하였다. 향 미의 품질 향상을 위한 로스팅 처리는 시간이 증가할수록 $\mathrm{L}$ 값은 감소하고 $\mathrm{a}$ 값 및 $\mathrm{b}$ 값은 증가하였다. 총 폴리페놀 및 총 플라보노이드 함량은 로스팅 처리 구간에서 각각 $37.41-41.65 \mathrm{mg} / \mathrm{g}$ 및 $21.93-22.30 \mathrm{mg} / \mathrm{g}$ 으로 무처리 구간
$33.00 \mathrm{mg} / \mathrm{g}$ 및 $20.78 \mathrm{mg} / \mathrm{g}$ 보다 전반적으로 증가하는 경향을 나타내었다. 아밀로오스 및 전분 함량 또한 로스팅 처리를 통해 25.06- $26.10 \mathrm{~g} / 100 \mathrm{~g}$ 및 76.38-81.81\%로 무처리구에 비해 증가하였다. DPPH 및 superoxide radical 소거활성 및 FRAP에서는 로스팅 처리한 향미벼에서 61.56-67.78\%, 43.14-52.90\% 및 0.72-0.79 mM을 나타내어 무처리 구간 보다 높은 소거활성을 나타내었다. 이상의 결과에서, 향미 를 $20 \%$ 도정한 다음 30 분 로스팅 처리로 인해 가공적성 및 항산화 활성이 증진되어 식품가공용 소재로 다양하게 활용 가능할 것으로 사료된다.

\section{감사의 글}

본 연구는 2017년도 농촌진흥청 어젠다사업(과제번호: PJ011647)의 연구비 지원에 의해 연구되었으며, 이에 감사 드립니다.

\section{References}

1. Seo SJ, Choi YG, Lee SM, Kong SH, Lee JS (2008) Antioxidant activities and antioxidant compounds of specialty rices. J Korean Soc Food Sci Nutr, 37, 129-135

2. Kim JS, Park OS, Ahn SN, Lee JR, Gwag JG, Kim TS, Lee SY (2008) Quantification of 2-acetyl-1-pyrroline from the aroma rice germplasm by gas chromatography. Korean J Food Sci Technol, 40, 516-521

3. De Kimpe NG, Stevens CV, Keppens MA (1993) Synthesis of 2-acetyl-1-pyrroline, the principal rice flavor component. J Agric Food Chem, 41, 1458-1461

4. Kim CY, Lee JC, Kim YH, Pyon JY, Lee SG (1999) Volatile flavor components of scent, colored, and common rice cultivars in Korea. Korean J Crop Sci, 44, 181-185

5. Lee JG, Im MH (2013) Effect of processing treatmen on physicochemical characteristics of brown rice varieties with different amylose content. Korean J Food Sci Technol, 45, 613-618

6. Han GJ, Lee HY, Park HJ, Park YH, Cho YS (2007) Cooking technique developoment to improve the taste of cooked rice: A consumer survey on purchasing rice and cooked rice consumption. Korean J Food Cookery Sci, 23, 452-460

7. Park JH, Han JS, Choi HK (1999) Effect on quality of pan-fired green tea by 1st pan firing time. Korean J Med Crop Sci, 7, 101-106 
8. Chung HS, Kim KJ, Youn KS (2006) Effects of roasting temperature on phycochemical properties of Job's tears (Coix lachrymajobi L. var. mayeun) powder and extracts. Korean J Food Preserv, 13, 477-482

9. Choi Y, Lee SM, Chun J, Lee HB, Lee J (2006) Influence of heat treatment on the antioxidant activities and polyphenolic compounds of Shiitake (Lentinus edodes) mushroom. Food Chem, 99, 381-387

10. Chandrasekara N, Shahidi F (2011) Effect of roasting on phenolic content and antioxidant activities of whole cashew nuts, kernels, and testa. J Agric Food Chem, 59, 5006-5014

11. Singleton VL, Rossi JA (1965) Colorimetry of total phenolics with phosphomolybdic-phosphotungstic acid reagents. Am J Enol Vitic, 16, 144-158

12. Davis WB (1947) Determination of flavonones in citrus fruits. Anal Chem, 19, 476-478

13. Williams PC, Kuzina FD, Hlynka I (1970) A rapid colorimetric procedure for estimating the amylose content of starches and flours. Cereal Chem, 47, 411-421

14. Blois MS (1958) Antioxidant determination by the use of a stable free radical. Nature, 181, 1199-1200

15. Nishikimi M, Rao NA, Yagi K (1972) The occurrence of superoxide anion in the reaction of reduced phenazine methosulfate and molecular oxygen. Biochem Biophys Res Commun, 46, 849-854

16. Benzie IFF, Strain JJ (1996) The ferric reducing ability of plasma (FRAP) as a measure of "antioxidant power": the FRAP assay. Anal biochem, 239, 70-76

17. Park JD, Choi BK, Kum JS, Lee HY (2006) Physicochemical properties of brown rice flours produced under different drying and milling conditions. Korean J Food Sci Technol, 38, 495-500

18. Kim OW, Kim H, Lee SE (2005) Color modeling of milled rice by milling degree. Korean J Food Preserv, 12, 141-145

19. Kim SR, Ahn JY, Lee HY, Ha TY (2004) Various properties and phenolic acid contents of rices and rice brans with different milling fractions. Korean J Food Sci Technol, 36, 930-936

20. Chun HS, You JE, Kim IH, Cho JS (1999) Comparative antimutagenic and antioxidative activities of rice with different milling fractions. Korean J Food Sci Technol, 31, 1371-1377
21. Tian S, Nakamura K, Kayahara H (2004) Analysis of phenolic compounds in white rice, brown rice, and germinated brown rice. J Agric Food Chem, 52, 4808-4813

22. Ali SZ, Bhattacharta KR (1972) Hydration and amylosesolubility behaviour of parbolied rice. Lebensm Wiss Technol, 5, 207-212

23. Lee SH, Kim MY, Kim HY, Ko SH, Shin MS (2010) Comparison of rice properties between rice grown under conventional farming and one grown under eco-friendly farming using hairy vetch. J Korean Soc Food Sci Nutr, 39, 1684-1690

24. Ko JY, Woo KS, Song SB, Seo HI, Kim HY, Kim JI, Lee JS, Jung TW, Kim KY, Kwak DY, Oh IS (2012) Physicochemical characteristics of sorghum tea according to milling type and pan-fried time. J Korean Soc Food Sci Nutr, 41, 1546-1553

25. Kwak JE, Oh SK, Kim DJ, Lee JH, Yoon MR, Kim HW, Lee JS (2013) Effects of heat-treated brown rice on total phenolics and antioxidant activities. J Korean Soc Food Sci Nutr, 42, 534-541

26. Lee YT (2006) Effect of heat treatments on in vitro starch hydrolysis of selected grains. J Korean Soc Food Sci Nutr, 35, 1102-1105

27. Koo SC, Jeon MG, Lee YH, Kim HY, Kang BK, Go JM, Baek IY, Yun HT, Choi MS (2014) Screening of soybean germplasm with high starch content. Korean J Breed Sci, 46, 52-57

28. Kim DJ, Oh SK, Yoon MR, Chun A, Hong HC, Lee JS, Kim YK (2010) Antioxidant compounds and antioxidant activities of the $70 \%$ ethanol extracts from brown and milled rice by cultivar. Korean J Breed Sci, 39, 467-473

29. Lee SH, Lee YR, Hwang IG, Woo KS, Kim KH, Kim $\mathrm{KJ}$, Jeong HS (2009) Antioxidant activities and quality characteristics of germinated rough rice tea according to roasting temperature, time and leaching condition. Korean J Food Sci Technol, 41, 386-391

30. Kirigaya N, Kato H, Fujimaki M (1968) Studies on antioxidant activity of nonenzymic browning reaction products: part I. relations of color intensity and reductones with antioxidan activity of browning reaction products. Agric Biol Chem, 32, 287-290 